Short Communication

\title{
Enhanced Nitrogen Removal of Eutrophic Water in Constructed Wetland by Novel Integration of Submerged Macrophyte Pond
}

\author{
Yi Ding ${ }^{1,2}$, Guangwei Lin ${ }^{1}$, Xingpo Liu ${ }^{1}$, Xinshan Song ${ }^{2 *}$ \\ ${ }^{1}$ College of Ocean Science and Engineering, Center for Marine Environmental and Ecological Modelling, \\ Shanghai Maritime University, Shanghai 201306, China \\ ${ }^{2}$ College of Environmental Science and Engineering, State Environmental Protection Engineering Center for Pollution \\ Treatment and Control in Textile Industry, Donghua University, Shanghai 201620, China
}

Received: 20 July 2021

Accepted: 31 October 2021

\begin{abstract}
Nitrogen pollution exacerbated water eutrophication and thus caused the rapid growth of algae. Constructed wetland (CW) could be blocked by excessive algae when removing nitrogen from eutrophic water. Submerged macrophytes were proved to be effective in decreasing algae survival and purifying nitrogen compounds. Therefore, submerged macrophyte pond (SMP) was integrated with CW to enhance nitrogen removal through intensifying nitrification and denitrification simultaneously. In hybrid system, algae-macrophyte photosynthesis in SMP improved oxygen environment of subsequent $\mathrm{CW}$, thus facilitating nitrification process of $\mathrm{CW}$. Residual algae debris from SMP effluents could be utilized as biodegradable carbon sources for subsequent $\mathrm{CW}$, thus promoting denitrification process of $\mathrm{CW}$. Nitrogen removal performance in hybrid system was significantly higher than that in single SMP and CW reactor due to carbon and oxygen enhancement, and the highest $\mathrm{NH}_{4}-\mathrm{N}$ and $\mathrm{TN}$ removals reached $62.1 \pm 2.0 \%$ and $60.4 \pm 2.0 \%$. The layer effect on nitrogen removal had been identified in $\mathrm{CW}$ unit, and optimal reductions of $\mathrm{NH}_{4}-\mathrm{N}$ and $\mathrm{TN}$ were obtained in the upper and bottom layer respectively. The study suggested that the hybrid system could be a cost-effective solution for reducing nitrogen and algae loads of eutrophic water.
\end{abstract}

Keywords: submerged macrophyte pond, constructed wetland, nitrogen removal, carbon and oxygen enhancement, algae inhibition

*e-mail: newmountain@dhu.edu.cn 


\section{Introduction}

With the rapid development of global economy and industrialization, a great number of nitrogen compounds were discharged into aquatic environment due to lack of cost-effective treatment, not only accelerating eutrophication of surface waters especially in the developing countries, but also causing algae outbreak that poses a major threat to drinking water quality and aquatic organisms' safety [1]. Therefore, removals of nitrogen compounds and algae biomass from eutrophic water have gained widespread attention worldwide. Constructed wetlands (CWs) are costeffective and eco-sustainable systems designed to treat various wastewaters especially for nitrogen removal [2]. Efficient nitrogen elimination in CWs is mainly achieved by nitrification and denitrification that are affected by the availability of dissolved oxygen and carbon source [3]. Most researches focus primarily on the strategies to intensify nitrification or denitrification individually, but the synergistic effect of nitrification and denitrification on comprehensive $\mathrm{TN}$ removal is neglected. Therefore, it is very necessary to enhance nitrification and denitrification simultaneously [4]. Although the addition of carbon sources and artificial aeration strategies could be the effective ways to improve carbon and oxygen level, these strategies are expensive and energy intensive [5-6]. Alternatively, algae biomass exists widely in eutrophic water and contains high quality protein and carbohydrates, which could be efficiently utilized by denitrifying bacteria as biodegradable organics in CWs [7]. Nevertheless, algae-laden water may lead to clogging phenomenon in the porous media when directly introduced into CWs.
Surplus algae should be controlled and eliminated for alleviating the processing load of CWs. Although traditional technologies (i.g. mechanical removal of algae and addition of chemical algaecide) could get certain performance, these strategies might give rise to energy consumption, high running costs and secondary pollution to water [8-9]. It is imperative to develop ecological restoration technology that could be integrated with $\mathrm{CWs}$ for algae inhibition and efficient nitrogen removal.

In this study, submerged macrophyte ponds (SMPs) are constructed to alleviate algae load and provide high quality effluents for CWs. When SMP was fed with eutrophic water, submerged macrophytes could inhibit the algae growth via excreting allelochemicals and competition absorption of nutrients [10]. In particular, macrophytes and microalgae in SMP can assimilate nitrogen and provide abundant oxygen via photosynthesis for nitrification of subsequent $\mathrm{CW}$ [11]. Residual algae debris in SMP effluents can act as a new source of organic matters for denitrification of subsequent $\mathrm{CW}$ [12]. The application of photosynthetic aeration and algal carbon source therefore save operation costs. The integration of SMP and CW form a cost-effective and eco-friendly purification system. However, the knowledge on the integration of SMP and $\mathrm{CW}$ as well as their common effect on nitrogen removal performance was unknown, thus impeding fully understanding of nitrogen removal in SMP-CW hybrid system. The study aims to evaluate the following aspects: (1) the variations of algae biomass, carbon and oxygen level, and nitrogen removal performance in experimental reactors (single SMP, single $\mathrm{CW}$, and hybrid system); (2) the influences of SMP on

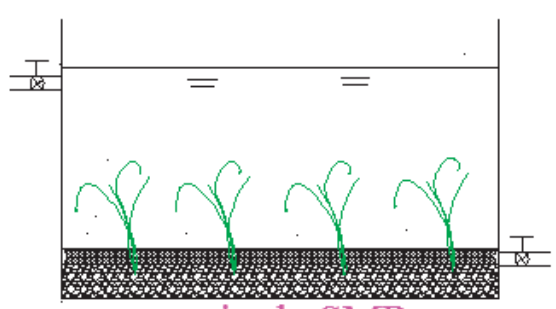

a. single SMP

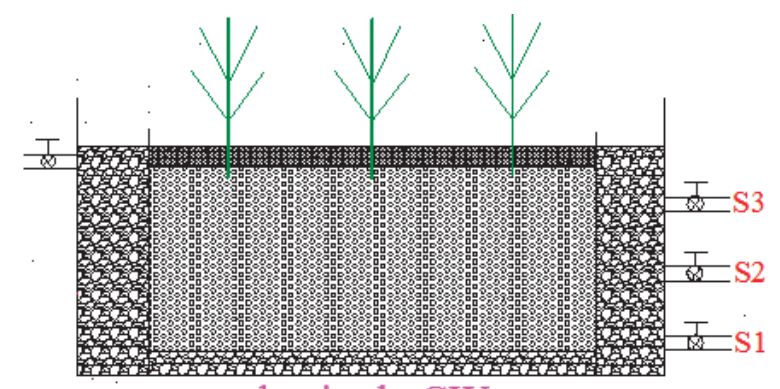

b. single CW

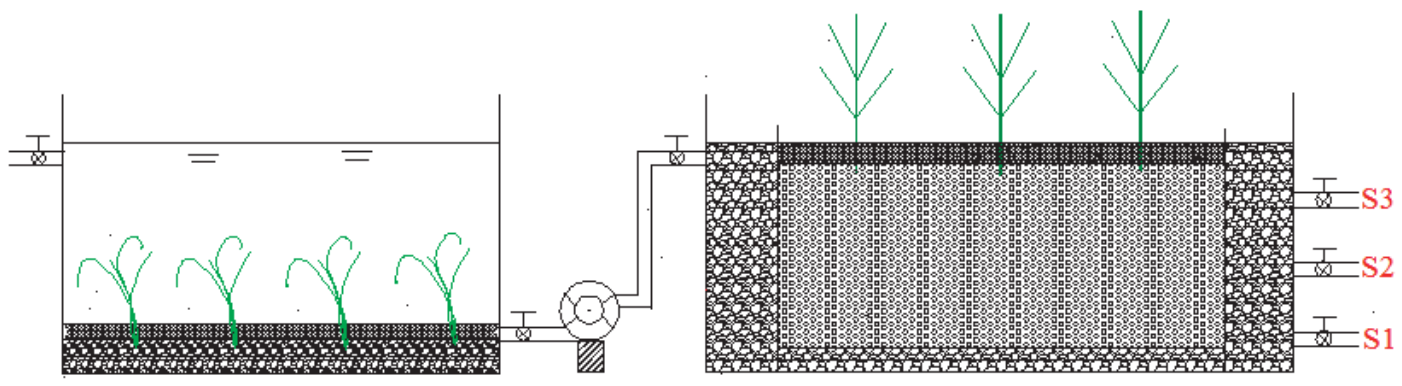

c. hybrid system

Fig. 1. Schematic diagram of experimental reactors: single SMP a), single CW b), and hybrid system c). 
algae inhibition and water purification; (3) the nitrogen removal performance of CW with/without SMP; and (4) the accurate understanding of synergistic mechanisms on nitrogen removal in hybrid system.

\section{Material and Methods}

Two lab-scale CWs $(200 \mathrm{~cm}$ length $\times 60 \mathrm{~cm}$ width $\times 70 \mathrm{~cm}$ depth) planted with eight Canna indica L. and two lab-scale SMPs $(96 \mathrm{~cm}$ length $\times 60 \mathrm{~cm}$ width $\times 60 \mathrm{~cm}$ depth) with Myriophyllum spicatum at a density of $7.5 \mathrm{~g} \mathrm{~L}^{-1}$ were constructed on Donghua University campus, Shanghai, China. The schematic diagram of experimental reactors is shown in Fig. 1. Each $\mathrm{CW}$ reactor was composed of three sections: inlet section $(20 \mathrm{~cm}$ length $\times 60 \mathrm{~cm}$ width $\times 70 \mathrm{~cm} \mathrm{depth})$, working section $(160 \mathrm{~cm}$ length $\times 60 \mathrm{~cm}$ width $\times 70 \mathrm{~cm}$ depth), and outlet section $(20 \mathrm{~cm}$ length $\times 60 \mathrm{~cm}$ width $\times 70 \mathrm{~cm}$ depth). The inlet and outlet sections were filled with $65 \mathrm{~cm}$ deep gravel (equivalent diameter of 3-4 cm). The middle working section was packed with $10 \mathrm{~cm}$ deep sand (equivalent diameter of $0.1-0.2 \mathrm{~cm}$ ) and $55 \mathrm{~cm}$ deep gravel (equivalent diameter of $1-2 \mathrm{~cm}$ ). Three sampling points were located at the outlet section with depths of $20 \mathrm{~cm}(\mathrm{~S} 1), 40 \mathrm{~cm}(\mathrm{~S} 2)$, and $60 \mathrm{~cm}(\mathrm{~S} 3)$ from the bottom. Each SMP reactor was filled with a $5 \mathrm{~cm}$ layer of washed sand $(0.1-0.2 \mathrm{~cm}$ in diameter) and a $10 \mathrm{~cm}$ layer of fine gravel $(1.5-2.0 \mathrm{~cm}$ in diameter). Inlet and outlet pipes were arranged on the two sides of each reactor, which could be individually switched on and off for convenient sampling.

This study was performed for five months (May to September) and experimental temperature was $25-35^{\circ} \mathrm{C}$. Single SMP and CW were individually operated in an intermittent way with hydraulic retention time (HRT) of 3 day. Hybrid system was operated in an intermittent way with 2-day HRT of SMP unit and 1-day HRT of CW unit. Synthetic eutrophic water was composed of $\mathrm{NH}_{4} \mathrm{Cl}, \mathrm{NaNO}_{3}$, glucose, $\mathrm{KH}_{2} \mathrm{PO}_{4}, \mathrm{MgCl}_{2}, \mathrm{FeSO}_{4}$ and Microcystis aeruginosa. Microcystis aeruginosa is a common bloom-forming cyanobacterium in freshwater ecosystems [10]. Synthetic eutrophic water was employed and introduced into each experimental system via peristaltic pumps. The total inflow was about $200 \mathrm{~L}$ within $1 \mathrm{~h}$. Main composition of the synthetic wastewater was shown in Table 1 and Table 2.

Influent and effluent samples of the experimental reactors were collected at $12 \mathrm{~h}, 24 \mathrm{~h}, 36 \mathrm{~h}, 48 \mathrm{~h}, 60 \mathrm{~h}$,

Table 1. Variations of algae biomass, DO, and COD with HRT in experimental reactors (a indicates S1 sampling outlet, b indicates S2 sampling outlet, and c indicates S3 sampling outlet).

\begin{tabular}{|c|c|c|c|c|c|}
\hline \multirow{2}{*}{ Parameters } & \multirow{2}{*}{ Influents } & \multirow{2}{*}{ Reactors } & \multicolumn{3}{|c|}{ Effluents } \\
\hline & & & 1d-HRT & 2d-HRT & 3d-HRT \\
\hline \multirow{7}{*}{$\begin{array}{c}\mathrm{DO} \\
\left(\mathrm{mg} \mathrm{L}^{-1}\right)\end{array}$} & \multirow{7}{*}{$6.5 \pm 0.5$} & Single SMP & $4.6 \pm 0.3$ & $7.5 \pm 0.3$ & $5.6 \pm 0.3$ \\
\hline & & \multirow{3}{*}{ Single CW } & $3.4 \pm 0.3^{\mathrm{c}}$ & $2.0 \pm 0.3^{\mathrm{c}}$ & $1.1 \pm 0.3^{\mathrm{c}}$ \\
\hline & & & $2.9 \pm 0.3^{b}$ & $1.5 \pm 0.3^{\mathrm{b}}$ & $0.7 \pm 0.3^{\mathrm{b}}$ \\
\hline & & & $2.1 \pm 0.3^{\mathrm{a}}$ & $0.8 \pm 0.3^{\mathrm{a}}$ & $0.2 \pm 0.1^{\mathrm{a}}$ \\
\hline & & \multirow{3}{*}{ Hybrid system } & \multirow{3}{*}{$4.8 \pm 0.3$} & \multirow{3}{*}{$7.9 \pm 0.3$} & $4.0 \pm 0.3^{\mathrm{c}}$ \\
\hline & & & & & $3.5 \pm 0.3^{\mathrm{b}}$ \\
\hline & & & & & $2.5 \pm 0.3^{\mathrm{a}}$ \\
\hline \multirow{5}{*}{$\begin{array}{l}\text { Algae biomass } \\
\left.\text { (cells } \mathrm{mL}^{-1}\right)\end{array}$} & $9230 \pm 60$ & Single SMP & $9571 \pm 60$ & $4905 \pm 60$ & $2758 \pm 60$ \\
\hline & -- & Single CW & - & -- & - \\
\hline & \multirow{3}{*}{$9368 \pm 60$} & \multirow{3}{*}{ Hybrid system } & \multirow{3}{*}{$9750 \pm 60$} & \multirow{3}{*}{$5125 \pm 60$} & $523 \pm 40^{\mathrm{c}}$ \\
\hline & & & & & $472 \pm 40^{\mathrm{b}}$ \\
\hline & & & & & $396 \pm 40^{\mathrm{a}}$ \\
\hline \multirow{7}{*}{$\begin{array}{c}\mathrm{COD} \\
\left(\mathrm{mg} \mathrm{L}^{-1}\right)\end{array}$} & \multirow{7}{*}{$71.0 \pm 4.0$} & Single SMP & $97.0 \pm 4.0$ & $82.0 \pm 4.0$ & $61.0 \pm 4.0$ \\
\hline & & \multirow{3}{*}{ Single CW } & $30.0 \pm 4.0^{c}$ & $11.0 \pm 2.0^{\mathrm{c}}$ & - \\
\hline & & & $32.0 \pm 4.0^{b}$ & $12.0 \pm 2.0^{\mathrm{b}}$ & - \\
\hline & & & $34.0 \pm 4.0^{\mathrm{a}}$ & $8.0 \pm 2.0^{\mathrm{a}}$ & -- \\
\hline & & \multirow{3}{*}{ Hybrid system } & \multirow{3}{*}{$92.0 \pm 4.0$} & \multirow{3}{*}{$80.0 \pm 4.0$} & $33.0 \pm 4.0^{\mathrm{c}}$ \\
\hline & & & & & $35.0 \pm 4.0^{\mathrm{b}}$ \\
\hline & & & & & $38.0 \pm 4.0^{\mathrm{a}}$ \\
\hline
\end{tabular}


Table 2. Nitrogen removal performances of experimental reactors (a indicates S1 sampling outlet, b indicates S2 sampling outlet, and c indicates S3 sampling outlet).

\begin{tabular}{|c|c|c|c|c|}
\hline Parameters & Influents (mg L'-1) & Reactors & Effluents $\left(\mathrm{mg} \mathrm{L}^{-1}\right)$ & Removal (\%) \\
\hline \multirow{7}{*}{$\mathrm{NH}_{4}-\mathrm{N}$} & \multirow{7}{*}{$23.2 \pm 1.0$} & Single SMP & $11.7 \pm 0.5$ & $49.6 \pm 2.0$ \\
\hline & & \multirow{3}{*}{ Single CW } & $12.0 \pm 0.5^{\mathrm{c}}$ & $48.3 \pm 2.0^{c}$ \\
\hline & & & $12.2 \pm 0.5^{b}$ & $47.4 \pm 2.0^{\mathrm{b}}$ \\
\hline & & & $12.5 \pm 0.5^{\mathrm{a}}$ & $46.1 \pm 2.0^{\mathrm{a}}$ \\
\hline & & \multirow{3}{*}{ Hybrid system } & $8.8 \pm 0.5^{\mathrm{c}}$ & $62.1 \pm 2.0^{c}$ \\
\hline & & & $9.0 \pm 0.5^{\mathrm{b}}$ & $61.2 \pm 2.0^{\mathrm{b}}$ \\
\hline & & & $9.4 \pm 0.5^{\mathrm{a}}$ & $59.5 \pm 2.0^{\mathrm{a}}$ \\
\hline \multirow{7}{*}{$\mathrm{NO}_{3}-\mathrm{N}$} & \multirow{7}{*}{$0.2 \pm 0.1$} & Single SMP & $3.2 \pm 0.2$ & -- \\
\hline & & \multirow{3}{*}{ Single CW } & $2.4 \pm 0.2^{\mathrm{c}}$ & -- \\
\hline & & & $2.2 \pm 0.2^{\mathrm{b}}$ & -- \\
\hline & & & $1.7 \pm 0.2^{\mathrm{a}}$ & -- \\
\hline & & \multirow{3}{*}{ Hybrid system } & $0.7 \pm 0.2^{\mathrm{c}}$ & -- \\
\hline & & & $0.5 \pm 0.2^{\mathrm{b}}$ & -- \\
\hline & & & $0.2 \pm 0.1^{\mathrm{a}}$ & -- \\
\hline \multirow{7}{*}{$\mathrm{TN}$} & \multirow{7}{*}{$24.0 \pm 1.0$} & Single SMP & $15.1 \pm 0.5$ & $37.1 \pm 2.0$ \\
\hline & & \multirow{3}{*}{ Single CW } & $14.6 \pm 0.5^{\mathrm{c}}$ & $39.2 \pm 2.0^{c}$ \\
\hline & & & $14.5 \pm 0.5^{b}$ & $39.6 \pm 2.0^{b}$ \\
\hline & & & $14.3 \pm 0.5^{\mathrm{a}}$ & $40.4 \pm 2.0^{\mathrm{a}}$ \\
\hline & & \multirow{3}{*}{ Hybrid system } & $9.9 \pm 0.5^{\mathrm{c}}$ & $58.8 \pm 2.0^{c}$ \\
\hline & & & $9.7 \pm 0.5^{b}$ & $59.6 \pm 2.0^{\mathrm{b}}$ \\
\hline & & & $9.5 \pm 0.5^{\mathrm{a}}$ & $60.4 \pm 2.0^{\mathrm{a}}$ \\
\hline
\end{tabular}

and $72 \mathrm{~h}$ to evaluate the variations of algae biomass, carbon and oxygen level, and nitrogen compounds in experimental reactors. Dissolved oxygen (DO) and temperature were determined in-situ using a DO meter (HI 9143, HANNA, Italy). Algae biomass was detected using a portable water quality multi-probe (Manta 2, EURERA, USA). Total nitrogen (TN), ammonia nitrogen $\left(\mathrm{NH}_{4}-\mathrm{N}\right)$, nitrate $\left(\mathrm{NO}_{3}-\mathrm{N}\right)$, and chemical oxygen demand (COD) were analyzed immediately using a multi-parameter colorimeter (DR900, HACH, USA) according to standard method.

The statistical analysis was conducted in triplicate and results were presented as mean \pm standard deviation. To estimate the significant differences between data sets in this study, one-way analysis of variance were performed using the Origin 8.0 statistical software (OriginLab, MA, USA) when $p$ value was below 0.05 .

\section{Results and Discussion}

Table 1 demonstrates the variations of algae biomass, DO, and COD with HRT in experimental reactors. The profiles of $\mathrm{DO}$ and $\mathrm{COD}$ in experimental reactors are shown in Fig. 2a) and Fig. 2b). As shown in Table 1 and Fig. 2a), DO content in single CW gradually decreased with HRT, which was mainly ascribed to the competition between nitrification and aerobic degradation of organics for depleting the available oxygen [13]. DO concentration in upper and middle layers of $\mathrm{CW}$ was better than that in the bottom layer of $\mathrm{CW}$, which was attributed to the atmospheric aeration and radial oxygen transportation of wetland plants [14]. In contrast, DO level in single SMP was significantly higher than that in single CW $(p<0.05)$ due to the photosynthetic aeration of algae and macrophytes. In hybrid system, DO detected in the effluent of CW unit ranged from $2.5 \pm 0.3 \mathrm{mg} \mathrm{L}^{-1}$ to $4.0 \pm 0.3 \mathrm{mg} \mathrm{L}^{-1}$, which was significantly higher than the variations $\left(0.2 \pm 0.1 \mathrm{mg} \mathrm{L}^{-1}\right.$ to $\left.1.1 \pm 0.3 \mathrm{mg} \mathrm{L}^{-1}\right)$ in effluents of single $\mathrm{CW}$ at $3 \mathrm{~d}-\mathrm{HRT}(p<0.05)$. The situation indicated that SMP promoted the oxygen environment of $\mathrm{CW}$ unit in hybrid system.

As illustrated in Table 1, effluent algae biomass of single SMP at $3 \mathrm{~d}$-HRT $\left(2758 \pm 60\right.$ cells $\left.\mathrm{mL}^{-1}\right)$ was significantly lower than that $\left(9230 \pm 60\right.$ cells $\left.\mathrm{mL}^{-1}\right)$ in influents $(p<0.05)$. The results indicated that Myriophyllum spicatum was conducive to inhibiting 


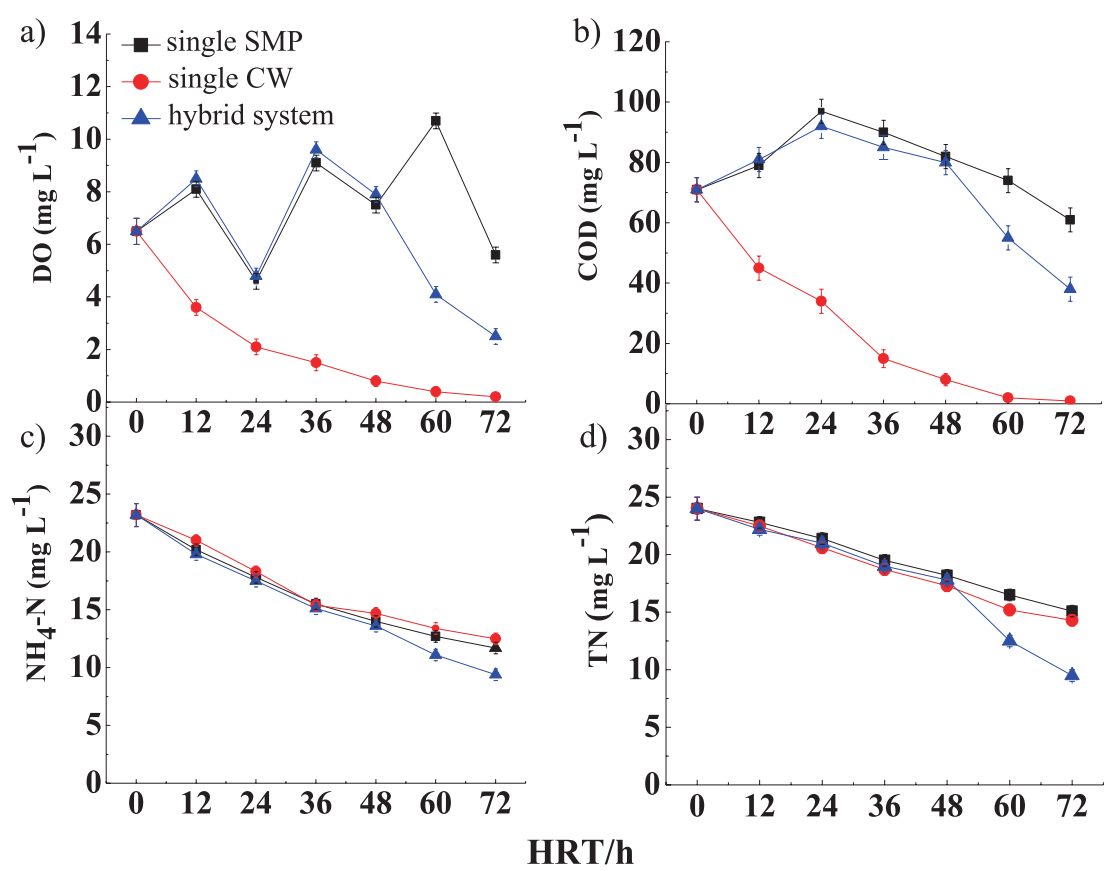

Fig. 2. Profiles of DO a), $\mathrm{COD} \mathrm{b}$ ), $\mathrm{NH}_{4}-\mathrm{N} \mathrm{c}$ ), and $\mathrm{TN}$ d) in experimental reactors.

algae growth, which was consistent with the results of Liu et al. [15]. In hybrid system, effluent algae biomass in different depths of $\mathrm{CW}$ unit ranged from $396 \pm 40$ cells $\mathrm{mL}^{-1}$ to $523 \pm 40$ cells $\mathrm{mL}^{-1}$, which was significantly lower than that $\left(5125 \pm 60\right.$ cells $\left.\mathrm{mL}^{-1}\right)$ in the effluent of SMP unit $(p<0.05)$. The main reason was that algae biomass gradually died when entering into the medium of $\mathrm{CW}$ due to lack of efficient photosynthesis [7]. Algae debris was then utilized by denitrifying bacteria as carbon sources for denitrification [16]. Reductions in algae biomass were greater with depth, where anaerobic environment contributed to the activity of denitrifying bacteria and the degradation of algae biomass.

As shown in Table 1 and Fig. 2b), COD content gradually decreased with HRT in single CW. At HRT of $3 \mathrm{~d}$, COD could not be detected at any depth of $\mathrm{CW}$. The situation implied that $\mathrm{CW}$ was faced with the discrepancy of carbon sources that was unfavorable to the occurrence of denitrification [17]. Although there was a decline trend in COD value of single SMP, effluent COD concentration at 3d-HRT $\left(61.0 \pm 4.0 \mathrm{mg} \mathrm{L}^{-1}\right)$ was significantly higher than that (close to $0 \mathrm{mg} \mathrm{L}^{-1}$ ) in single $\mathrm{CW}$. This phenomenon could be explained by the fact that effluent algae biomass promoted COD content as biodegradable organics. In hybrid system, COD detected in the effluent of $\mathrm{CW}$ unit ranged from $33.0 \pm 4.0 \mathrm{mg} \mathrm{L}^{-1}$ to $38.0 \pm 4.0 \mathrm{mg} \mathrm{L}^{-1}$, which was significantly higher than that (close to $\left.0 \mathrm{mg} \mathrm{\textrm {L } ^ { - 1 }}\right)$ in single $\mathrm{CW}$ at $3 \mathrm{~d}-\mathrm{HRT}(p<0.05)$. Algal carbon sources obviously improved the COD level of $\mathrm{CW}$ unit.

$\mathrm{NH}_{4}-\mathrm{N}$ removal mechanisms in hybrid system mainly included algae assimilation, macrophyte uptake, substrate adsorption, and aerobic nitrification [18-20].
As shown in Table 1 and Fig. 2c), $\mathrm{NH}_{4}-\mathrm{N}$ concentration decreased gradually with HRT in experimental reactors. The removal performance of $\mathrm{NH}_{4}-\mathrm{N}$ in hybrid system was significantly higher than that in single SMP and $\mathrm{CW}$ due to the integrated mechanisms for $\mathrm{NH}_{4}-\mathrm{N}$ removal $(p<0.05)$. Abundant DO in SMP unit of hybrid system promoted the aerobic nitrification occurrence of subsequent $\mathrm{CW}$ unit, thus facilitating the conversion and removal of $\mathrm{NH}_{4}-\mathrm{N}$. $\mathrm{NH}_{4}-\mathrm{N}$ reductions were greater in the upper and middle layer of planted $\mathrm{CW}$ than that in the bottom layer, where the oxygen environment was optimal due to atmosphere reaeration and radial oxygen transportation [14]. Effluent $\mathrm{NO}_{3}-\mathrm{N}$ concentration in single SMP reached $3.2 \pm 0.2 \mathrm{mg} \mathrm{L}^{-1}$, which implied that denitrification was inhibited by the overall aerobic conditions. Effluent $\mathrm{NO}_{3}-\mathrm{N}$ concentration in single $\mathrm{CW}$ ranged from $1.7 \pm 0.2 \mathrm{mg} \mathrm{L}^{-1}$ to $2.4 \pm 0.2 \mathrm{mg} \mathrm{L}^{-1}$, which indicated that carbon source was not sufficient for efficient occurrence of denitrification. By contrast, $\mathrm{NO}_{3}-\mathrm{N}$ detected in the effluent of hybrid system ranged from $0.2 \pm 0.1 \mathrm{mg} \mathrm{L}^{-1}$ to $0.7 \pm 0.2 \mathrm{mg} \mathrm{L}^{-1}$, which was significantly lower than that in single SMP and CW $(p<0.05)$. Adequate content of algal carbon source in SMP effluents promoted the denitrification of subsequent $\mathrm{CW}$ unit, thus facilitating the reduction of accumulated $\mathrm{NO}_{3}-\mathrm{N}$. $\mathrm{NO}_{3}-\mathrm{N}$ reductions were greater in the bottom layer of $\mathrm{CW}$ than that in the upper and middle layer, where the anaerobic conditions conduced to efficient denitrification [21].

In this study, $\mathrm{TN}$ was mainly composed of $\mathrm{NH}_{4}-\mathrm{N}$ and $\mathrm{NO}_{3}-\mathrm{N}$. As shown in Table 1 and Fig. 2d), TN concentration showed a decreased trend with HRT in experimental reactors. Deviations between $\mathrm{TN}$ and $\mathrm{NH}_{4}-\mathrm{N}$ removals $(37.1 \pm 2.0 \%$ and $49.6 \pm 2.0 \%)$ in single SMP reached $12.5 \pm 2.0 \%$, which implied that $\mathrm{TN}$ 
reduction was affected by $\mathrm{NO}_{3}-\mathrm{N}$ accumulation due to the aerobic conditions unfavorable for the occurrence of denitrification. $\mathrm{TN}$ removal in single $\mathrm{CW}$ ranged from $39.2 \pm 2.0 \%$ to $40.4 \pm 2.0 \%$, which exhibited similar removal efficiency with single SMP due to lack of sufficient oxygen and carbon content thus causing incomplete nitrification and denitrification. Efficient removal of $\mathrm{TN}(58.8 \pm 2.0 \%$ to $60.4 \pm 2.0 \%)$ could be achieved in hybrid system, which was significantly higher than that in single SMP and CW $(p<0.05)$. Carbon and oxygen enhancement from SMP unit facilitated the nitrification and denitrification reaction of subsequent $\mathrm{CW}$ unit, which eventually exerted a negative effect on $\mathrm{TN}$ reduction. $\mathrm{TN}$ reductions were greater in the bottom layer of $\mathrm{CW}$ than that in the upper and middle layer. This phenomenon could be explained by two facts: (1) although aerobic conditions in the upper and middle layer promoted the conversion of $\mathrm{NH}_{4}-\mathrm{N}$ into $\mathrm{NO}_{3}-\mathrm{N}$, nitrogen compounds were not removed from water body thus influencing TN removal; (2) anaerobic conditions in bottom layer promoted the conversion of $\mathrm{NO}_{3}-\mathrm{N}$ into $\mathrm{N}_{2}$ or $\mathrm{N}_{2} \mathrm{O}$, which contributed to complete $\mathrm{TN}$ removal.

\section{Conclusions}

Nitrogen removal of eutrophic water in $\mathrm{CW}$ was usually subject to insufficient carbon and oxygen content, and excessive algae-laden water could aggravate the substrate clogging and affect $\mathrm{CW}$ performance. In SMP-CW hybrid system, abundant DO from algae-macrophyte photosynthesis of SMP promoted aerobic nitrification occurrence of subsequent $\mathrm{CW}$ unit, which could be a cost-effective oxygenation method. Additionally, excessive algae could be ecologically eliminated in SMP and then utilized as biodegradable carbon sources for denitrification of $\mathrm{CW}$. Novel integration of SMP and CW was conducive to exerting synergistic effects on intensifying nitrogen removal performance. The aerobic condition of upper and middle layers in $\mathrm{CW}$ was beneficial for $\mathrm{NH}_{4}-\mathrm{N}$ removal while the anoxic and anaerobic condition of the bottom layer was conducive to $\mathrm{NO}_{3}-\mathrm{N}$ reduction and TN removal. This study implied that SMP-CW hybrid system could be a cost-effective restoration technology for enhancing nitrogen removal and algae inhibition of eutrophic water.

\section{Acknowledgment}

This study was supported by the National Natural Science Foundation of China (grant No. 51809162) and National Key Research and Development Project (grant No. 2019YFC0408604).

\section{Conflict of Interest}

The authors have not declared any conflict of interest.

\section{References}

1. WANG Y.M., LIN Z.Y., WANG Y., HUANG W., WANG J.L., ZHOU J., HE Q. Sulfur and iron cycles promoted nitrogen and phosphorus removal in electrochemically assisted vertical flow constructed wetland treating wastewater treatment plant effluent with high $\mathrm{S} / \mathrm{N}$ ratio. Water Res., 151, 20, 2019.

2. KUJALA K., KARLSSON T., NIEMINEN S., RONKANEN A.-K. Design parameters for nitrogen removal by constructed wetlands treating mine waters and municipal wastewater under Nordic conditions. Sci. Total Environ., 662, 559, 2019.

3. JIA L.X., WANG R.G., FENG L.K., ZHOU X., LV J.L., WU H.M. Intensified nitrogen removal in intermittentlyaerated vertical flow constructed wetlands with agricultural biomass: Effect of influent $\mathrm{C} / \mathrm{N}$ ratios. CHEM. ENG. J., 345, 22, 2018.

4. LIU Y., LIU X.H., LI K., LU S.Y., GUO X.C., ZHANG J., XI B.D. Removal of nitrogen from low pollution water by long-term operation of an integrated vertical-flow constructed wetland: Performance and mechanism. Sci. Total Environ., 652, 977, 2019.

5. ZHOU X., WANG X.Z., ZHANG H., WU H.M. Enhanced nitrogen removal of low $\mathrm{C} / \mathrm{N}$ domestic wastewater using a biochar-amended aerated vertical flow constructed wetland. Bioresour. Technol., 241, 269, 2017.

6. JU X.X., WU S.B., ZHANG Y.S., DONG R.J. Intensified nitrogen and phosphorus removal in a novel electrolysisintegrated tidal flow constructed wetland system. Water Res., 59, 37, 2014.

7. DING Y., WANG W., LIU X.P., SONG X.S., WANG Y.H., ULLMAN J.L. Intensified nitrogen removal of constructed wetland by novel integration of high rate algal pond biotechnology. Bioresour. Technol., 219, 757, 2016.

8. LI J.H., YANG X.Y., WANG Z.F., SHAN Y., ZHENG $Z$. Comparison of four aquatic plant treatment systems for nutrient removal from eutrophied water. Bioresour. Technol., 179, 1, 2015.

9. FREEMAN A.I., SURRIDGE B.W.J., MATTHEWS M., STEWART M., HAYGARTH P.M. New approaches to enhance pollutant removal in artificially aerated wastewater treatment systems. Sci. Total Environ., 627, 1182, 2018.

10. DING Y., SUN Y., TANG H.Y., SONG X.S. Effects of macrophytes species and density on algae inhibition and water purification in submerged macrophyte ponds. Polish J. of Environ. Stud., 29 (5), 3451, 2020.

11. DING Y., WANG Y.H., LIU X.P., SONG X.S. Improving nutrient and organic matter removal by novel integration of a high-rate algal pond and submerged macrophyte pond. Polish J. of Environ. Stud., 29 (1), 997, 2020.

12. BOSHOFF G., DUNCAN J., ROSE P.D. The use of microalgal biomass as a carbon source for biological sulphate reducing systems. Water Res., 38 (11), 2659, 2004.

13. LIU L., ZHAO X.H., ZHAO N., SHEN Z., WANG M., GUO Y.Z., XU Y.B. Effect of aeration modes and influent $\mathrm{COD} / \mathrm{N}$ ratios on the nitrogen removal performance of vertical flow constructed wetland. Ecol. Eng., 57, 10, 2013. 
14. WANG W., DING Y., ULLMAN J.L., AMBROSE R.F., WANG Y.H., SONG X.S., ZHAO Z.M. Nitrogen removal performance in planted and unplanted horizontal subsurface flow constructed wetlands treating different influent COD/N ratios. Environ. Sci. Pollut. Res., 23, 9012, 2016.

15. LIU Q., SUN B., HUO Y.Z., LIU M.M., SHI J.T., JIANG T., ZHANG Q., TANG C.Y., BI H.S., HE P.M. Nutrient bioextraction and microalgae growth inhibition using submerged macrophyte Myriophyllum spicatum in a low salinity area of East China Sea. Mar. Pollut. Bull., 127, 67, 2018.

16. BOSHOFF G., DUNCAN J., ROSE P.D. The use of microalgal biomass as a carbon source for biological sulphate reducing systems. Water Res., 38 (11), 2659, 2004.

17. FU G.P., HUANGSHEN L., GUO Z.P., ZHOU Q.H., WU Z.B. Effect of plant-based carbon sources on denitrifying microorganisms in a vertical flow constructed wetland. Bioresour. Technol., 224, 214, 2017.
18. LIN Q.S., GU B.H., HONG J.M. Tracking uptake of submerged macrophytes (Ceratophyllum demersum) Derived nitrogen by cattail (Typha angustifolia) using nitrogen stable isotope enrichments. Ecol. Eng., 99, 114, 2017.

19. HUA G.F., LI J.L., CHENG Y., KONG J., LIU X.D., SHI Y., HUANG Y.Y. Efficiencies of nitrogen removal in slopeconstructed wetlands. Polish J. of Environ. Stud., 30 (3), 2107, 2021.

20. DING Y., WANG Y.H., LIU X.P., SONG X.S., FENG D.L. High-rate algal pond coupled with polyester fiber strips for organics and nutrient removal in a cold climate. Polish J. of Environ. Stud., 28 (5), 4039, 2019.

21. LIU S.Y., YAN B.X., WANG L.X. The layer effect in nutrient removal by two indigenous plant species in horizontal flow constructed wetlands. Ecol. Eng., 37 (12), 2101, 2011. 